Abrossimova, L., Bogdanova, M. \& Snezhko, G. (2020). Classical university crisis: new challenges and prospects of Russian higher education, International Journal of Cognitive Research in Science, Engineering and Education (IJCRSEE), 8(3), 135144.

Review Article

UDK:

Received: September, 18.2020

Revised: November, 27.2020.

Accepted: December, 02.2020 .

doi: $10.23947 / 2334-8496-2020-8-3-135-144$

\title{
Classical University Crisis: New Challenges and Prospects of Russian Higher Education
}

\author{
Larisa Abrossimova ${ }^{1 *}$, Marina Bogdanova², Galina Snezhko³
}

\begin{abstract}
${ }^{1}$ Southern Federal University; Institute of Philology, Journalism and Intercultural Communication; Department of Theory and Practice of the English Language, Rostov-on-Don, Russian Federation, e-mail: lara.abrossimova@mail.ru ${ }^{2}$ Southern Federal University; Institute of Philosophy and Socio-Political Sciences; Department of the History of Russian and foreign Philosophy, Rostov-on-Don, Russian Federation, e-mail: maraleks27@mail.ru

${ }^{3}$ Director of Rostov Regional Centre for Information Processing in Education, Ministry of Education of Rostov Region, Russian Federation, e-mail: rocoiso@rostobr.ru
\end{abstract}

\begin{abstract}
The objective of the paper is to discuss the most crucial problem, related to "winding down" of the Russian Liberal Arts education due to its economic inefficiency. The methodology includes the descriptive scientific-research method, which involves the analysis of scientific sources, official provisions, mass-media publications and the students' questionnaire. The authors came to the following conclusions: 1 . The model of education, which is guided by the logic of economic growth, and not by the logic of human development, leads to a general dehumanization of education and society. 2 . The process of education "dehumanizing" is manifested in the following destructive trends: pragmatic utility and convenience of gaining knowledge; the dominance of technical knowledge and the transfer of humanitarian disciplines into optional courses; the advance of online education; the imperfection of university lecturers' ratings and their transformation into a bureaucratic evaluation system; new types of inequality in education. 3. In Russia, the above-mentioned trends are aggravated by the abnormal establishment of market economy; the verticalization of power and the lack of professionalism in university management; social sphere underfunding; the aggressive implementation of the Bologna system. 4. The current crisis in education is accompanied by the large-scale emigration of gifted students and lecturers. The authors recommend to consider the University as a classical "home" of formation, preservation and transfer of culture; online courses should be seen as a new format of teaching aids, as well as a technological tool for retraining and for people with disabilities.

Keywords: Liberal Arts education, educational crisis, online education, utilitarianism and pragmatism, the Bologna process.
\end{abstract}

\section{Introduction}

These days the tension in the sphere of education has become acute, therefore it is necessary to speak out of the long-standing problem, related to the crisis state of the Liberal Arts education, which has become even worse during the lingering COVID-19 lockdown. There is a clear understanding of the fact that the humanitarian community cannot just observe the escalating negative changes in the life of the modern University education in Russia, but has to raise its voice against the postmodern games, aimed at "dehumanizing the human".

The ongoing educational crisis, which has especially affected Humanities, has been talked about openly, as its signs are now obvious not only to the experts, but to all who teach and study. For this reason, it is essential for the modern society to protect Liberal Arts education as an independent and selfsufficient cycle of education, but not supplementary to Science or Technology.

Thus, the main objective of the current paper is to reveal the reasons and the impact of recent transition to full-scale on-line education in Russia, to analyze the research of specialists in different fields, predict the far-reaching effects of this transition and propose some recommendations on how to improve the situation.

\section{Historical Transformations of University Education}

This part of the paper will focus not only on the historical transformation of university education, but also on a critical philosophical understanding of the history of the university and its role in the modern world. There are a lot of authoritative works devoted to this theme, including "The Idea of the University"

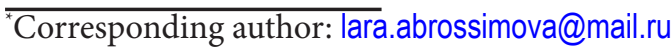


(1959) by K. Jaspers, who explores the change in the very idea of the university, which consists in the unity and interaction of three elements: professional training, upbringing (education) and scientific research. "The Postmodern Condition: a Report on Knowledge" (1984) by J. Lyotard, who, in the chapter "Education and Its Legitimation through Performativity," states that "universities and the institutions of higher learning are called upon to create skills, and no longer ideals - so many doctors, so many teachers in a given discipline, so many engineers, so many administrators, etc." (Lyotard, 1984, p. 48) "University in Ruins" (1997) by B. Readings associates the negative transformations of the university with the processes of globalization and the loss of the national-cultural mission. "The Idea of the University" (1992) by J. Pelikan traces the historical development of university education over eight centuries.

The history of European University education goes back centuries, during which it has proved its social and cultural significance.

The first European Universities (the Universities of Bologna, Paris, Oxford and Salamanca) were founded in the XI-XII centuries and had a prominent humanitarian orientation. These Universities included four faculties: the Junior (Pre-University) or Seven Liberal Arts faculty and three Senior ones - Medicine, Law and Theology faculties. Educational establishments of the ancient times, such as rhetoric schools in Athens, the Law school of Berytus and the University of Constantinople, can be tentatively called the predecessors of the medieval Universities.

The founding of the first European Universities was driven by the development of feudal cities, trade and crafts as well as the complication of social life. All these changes demanded the output of specialists in Law, Medicine and Theology. Despite the fact that University education was only beginning to gain popularity in society, the first graduates showed their ability to accomplish major social tasks, such as governing the state and maintaining law and order, developing the spiritual life of society as well as accelerating enlightenment and healthcare.

The changes in socio-economic conditions, which were brought to European countries by the era of the industrial revolution, put the future of University education into question. The "old" European University, in which Theology and Humanism were the backbone of the whole system, did not comply with the "spirit of capitalism". The appearance of the liberalistic and utilitarian educational models signified the establishment of new educational paradigms. The value systems, which they asserted, were sometimes oppositional like those of University education, but in general, they corresponded to the new socioeconomic formation.

Supporters of liberal education thought that the mission of the University was to form free spirit and whole personalities by means of classical literature and arts. They believed that the aim of education was to meet individual, but not social needs. In fact, this model reflects the understanding of education as the ancient paideia, which was focused on the improvement of a person's soul.

The followers of utilitarian educational model prioritized the utility of education and saw the aim of the University in providing students with high-grade practical vocational training. They were convinced that the educational system had to be free for all and solve vital social problems, while the development of a person's spiritual potential was a matter of free expression. This notion of education and its aims reflects the viewpoint of sophists, who considered education to be a tool for training practical workers to perform major social functions.

In the XIX century, Wilhelm von Humboldt suggested a new model of the "Ideal University", which was able to combine personal and social needs in the process of studying. This was seen as education with the enhanced character building function and was based on a considerable framework of Humanities. As this model became widely practiced in Europe, it made a significant contribution to a strong cultural development of European countries. The teacher-student relationship was based on the principles of freedom and equality, and this created a special intellectual University environment, which later nurtured many great scientists and artists.

Humboldt suggested that there was a connection between a citizen's level of education and prosperity. He believed education to be the key to the rise in the social hierarchy and the tool for fair income transfer to well-educated people.

The "Ideal University" model was based on the union between knowledge and power, which implied a certain agreement. While scientists strived to have wider institutional opportunities and academic freedoms, the government's demand from Universities was to maintain national culture and assist in forming citizens' personalities as patriotic to their country and national symbols.

In the middle of the XIX century, a revolutionary idea, that transition to mass education would activate economic upturn, took root in society. This, once again, lead to intense discussions regarding the future of University education. The authors shared their conceptions of the strategic goal, which would reflect the sense and mission of the University in the changed world. The sharpening of the debate was 
caused by the so-called "scissor" problem - a gap between the volume of the ever-increasing scientific knowledge and the limited abilities of sharing it, as well as by rapid outdating of information in the midst of the technology boom.

Differentiation and diversification of the higher education systems appeared as a means of adapting to the new historical and cultural conditions. Many educational establishments of the new type appeared parallel to (but not instead of) traditional humanistic Universities, such as Technical Institutes, Colleges, Polytechnic Schools and technical-oriented distance learning centres. This innovation provided new opportunities to meet the increasing demands of business and government in technical and executive personnel.

The educational model, based on the economic growth logic, started to dominate over the personal growth logic model. Just then, the ideologists of economism and technocracism raised their voice. They stated that the elitist education contributed to the stratification of society, asserted the dominance of one class over the other and hindered democracy and justice besides to being expensive and conservative.

The so-called mass University took the place of the genuine elitist University education. Among its feature tendencies, there were the increasing number of students, the unification of higher education, the adjustment of teaching programs and methods to average ability students, disassociation from research activities and growth of pragmatism and utilitarianism in education. Besides that, what we are facing now is the transition to online education.

\section{The Current State of University Education in Russia}

This part of the paper goes into the modern trends of the current University Education in the Russian Federation. To discover these trends, the following methods were used: the descriptive scientific-research method, which involves the analysis of scientific sources, official provisions, mass-media publications, a students' questionnaire and data analysis. The use of the methodology allowed distinguishing the following problems.

\section{1. «Snack learning»}

The hideous development of market economy, unfortunately, could not but affect the modern education in Russia, turning it into another market sector for the production, distribution, exchange and consumption of "educational products and services". Having to comply with the law and becoming a commodity, education loses its significant principles - imperativeness and insistence. According to T. Khagurov (2010, p. 101), "At present, the imperativeness of education disappears, giving way to consumer preferences". It is evident that these consumer preferences get applied within the educational system of Russia. Among them, there are quick graduation (the "snack learning"), limited specialization (the "micro-degree" and "micro-master's degree"), lack of academism and fragmentary educational content the "distracted learning" (Kuzminov and Frumin, 2015), reduction of Humanities ("dehumanitarization" of education), pragmatic utility of knowledge and simplification of the learning process (the "light version" of higher education) (Gottlieb, 2016).

Consumer policies of the mass culture, which promote hedonism and consumerism as "values", show studying as an easy and effortless process. Hence, the "educational product" gets adapted to the consumer requirements and undergoes compulsory simplification and "massification". It is then presented as a cheap mass-market product from a retail network.

It is a known fact that the possibility of getting education without effort tends to demoralize both the student and the whole society.

\section{Literature, Art, Ethics, Aesthetics and Philosophy Get "Thrown Overboard"}

Under such circumstances, Russian Universities have almost given up on providing their students with knowledge, focused on morality and spiritual growth, thus having neglected the purpose of the classical University. Most of Russia's modern Universities have turned into a mass output of "specialists", whose priorities are "being able to do" and "possessing competences" rather than "knowing". Young people's attention gets fully concentrated on relative values and know-how, on what can be obtained "on the spot" and quickly converted into profit. The dominance of technical knowledge in the modern University system leads to Literature, Art, Ethics and Aesthetics getting "thrown overboard" (Abrosimova and Bogdanova, 2011, p. 14). As Paul Keen (Keen, 2014, p. 75-76) points out the government of England decided to cancel funding for teaching humanities in 2010 which was caused by a new concept of so-called "impact of research" parameters; Canada cancelled the Ontario Research Fund focusing on Social Sciences, Arts, and Humanities, choosing to prioritize "real-life problems" research on universities' curricula.

Formally, the curricula of the Natural Science departments still contain some of the Liberal Arts 
classes, however, both students and teachers believe these subjects to be worthless. Due to this fact, the Humanities are oftentimes reduced to trial courses or given within the framework of online general lectures for a huge audience. Liberal education is incompatible with crowded lecture theatres and large audiences, which make the discussion of life-purpose questions impossible. Thus, complex questions and problems of existence and worldview get either banished from University standards or severely emasculated. Even on Arts faculties, such subjects as Logic, Rhetoric, Culture Studies, Ethics and Aesthetics are either not taught at all or offered as optional elective courses.

The fate of Philosophy is none the less tragic. The 120-hour in-class training course, which, until recently, was given during a full-year cycle on non-philosophical faculties, has now been reduced to 38 in-class hours and is expected to be placed fully online anytime soon. These changes are considered to be absolutely contrary to the very nature of the main humanitarian subject. It is known, that Philosophy appears in the history of European culture as a school, where the teacher-student relationship is achieved through a conversation - a genuine dialogue, which can only be possible "offline". A philosophical message cannot be delivered via any device, but requires a specific intellectual and emotional environment, which implies person-to-person interaction. Otherwise, if there is an online discussion, the notions of space, time and communication form a completely different dimension - they become "dehumanized" and lose their sacral essence.

The state support of Humanities is insignificant. The government no longer sees Liberal Arts education as worthy of support. This statement can be proved by the fact that none of Humanitarian or Social sciences have been listed among priority scientific directions. Higher School of Economics, having a special status, has become the only Humanities University among the National Research Universities (NRU). All other NRUs are either Technical, Technology, Engineering and Medical establishments or Universities, which still offer some Humanities programs, but mainly focus on Sciences (https://strategy. hse.ru/list). Russian Foundation for Humanities, though being the major support tool for Humanities studies in Russia, does not possess sufficient capacities for supporting Humanities researchers.

According to business managers, Humanities have been downgrading Universities, undermining their branding and even "taking down" the whole educational system of Russia. Once an indisputable truth, the fact that History, Language, Literature and the like subjects make young people think, doubt, ask questions and determine their personalities is disregarded. It is important to understand these days that social welfare evaluation does not always correlate with the GDP growth record.

\section{The Expansion of Online Education}

"Online education", "online teachers", "online students", "online educational product", etc. - these notions have been widely used in educational contexts recently. Egalitarization of higher education, the focus on including Russian education in the global agenda, the questioned economic efficiency of traditional education and COVID-19 indicate the full-scale expansion of online education beginning with the gradual exclusion of traditional educational models which eventually will result in the maximum transfer of study process into the global net.

As the process is comparatively new, there are a lot of controversies in today's research (Abakumova et al., 2019; Pedro et al., 2018; Shirky, 2014; Makarova, A. E., and Makarova, L. E., 2018; Sana et al., 2013). Some scholars concentrate on the positive sides of distance education, whereas others try to find and describe downsides. There have been numerous studies to investigate "pros and cons" of distance learning, selected and defined by different scholars and practitioners. Nevertheless, nobody can predict the farreaching effects of e-learning either on people's physical and mental health or on social relationships. The possibility to "learn anything at anytime and anywhere" requires substantial human resources, and, as Pedro and Santos (2018) point out, "the classroom dynamics are becoming more and more at risk with the addictive dimension brought about by the ubiquitous presence of digital devices and social media in students' lives."

The literature review shows that research articles state opposite opinions. The majority underline the advantages provided by online education. Abakumova et al. $(2019$, p. 89$)$ stress the positive impact of distance learning on the teacher-student relationship, as well as on students' creative abilities and their cognitive development in general: "In distance learning, taking into account the model of translational learning and the use of all available telecommunication channels, the teacher-learner's communication is more intimate, since it is more accessible in time and space, and secondly more individualized and personified. That also contributes to the initiation of cognitive activity of students. The development of students' creative abilities, using creative and semantic tasks is an important quality of distance education". Shirky (2014, p. 368) expresses the opposing view, arguing that on-line learning imposes a multitasking burden on students, which "can have negative long-term effects on "declarative memory", the 
kind of focused recall that lets people characterize and use what they learned from earlier studying". Sana et al. (2013, p. 24) share the above-mentioned opinion, arguing that "participants who multitasked on a laptop during a lecture scored lower on a test compared to those who did not multitask, and participants who were in direct view of a multitasking peer scored lower on a test compared to those who were not. The results demonstrate that multitasking on a laptop poses a significant distraction to both users and fellow students and can be detrimental to comprehension of lecture content".

Southern Federal University (SFedU, Rostov-on-Don, Russia) launched a survey of students' attitudes towards online learning at the beginning of the compulsory transfer to online format due to COVID pandemic. Data were collected and maintained by the Institute of Sociology and Regional Studies of SFedU on 9-14 April 2020. The analysis was conducted on 13-18 April 2020. The type pf the survey is a questionnaire conducted via the Internet-server Anketolog.ru (https://anketolog.ru). There were 2739 participants in this sample who constitute $11 \%$ of the total students' body.

There were two sections in the questionnaire: 1 ) the elements of positive attitude towards distance learning and 2) difficulties in introducing a distance learning system at SFedU.

Regarding the first element, $42.5 \%$ of the respondents consider traditional forms of education to be more interesting; $18.1 \%$ suppose that the current state of distance learning in SFedU does not make it possible to use all its possibilities; almost a third of the respondents (30.5\%) consider distance education to be advantageous, since it provides more opportunities for acquiring knowledge and saves time. $26.2 \%$ think that e-learning forms digital skills and develops independence in finding and processing the necessary information. $33.2 \%$ stress that distant learning develops self-control skills; $20.8 \%$ underline motivation for self-education; $21.5 \%$ - ease of updating the content and the possibility of archiving old materials, which remain available for downloading. The largest percentage is found outside academic advantages: $74.7 \%$ marked saving time and money (mainly on commuting) and $48.6 \%$ - learning in a comfortable and familiar environment. Nevertheless, only 15,4\% of students underline the positive impact of technologization of the learning process (use of information technologies).

In regard to the second part of the questionnaire (Difficulties in introducing a distance learning system at SFedU) the students' answers reveal the following problems: technical difficulties with the installation and use of remote training software (14.9\%); methodological unpreparedness of the teaching staff to implement distance learning (17.5\%); insufficient level of teachers' digital literacy - $24.7 \%$; lack of the necessary methodological base (electronic textbooks, video training programs, presentations) that would ensure effective work in a distance mode (17.5\%); lack of a personal computer / laptop for students to fully participate in the distance learning (19.6\%); inefficiency of dean's offices in solving technological problems (5.1\%). The largest percentage of students marked the poor quality of the Internet connection, which prevents full participation (53.7\%) and physical fatigue from constant work with a computer / laptop (47.9\%). Only $13.3 \%$ chose "no difficulties" option.

We performed additional data collection with the students of the humanitarian departments of SFedU in June 2020, after two months of full-scale online learning. The respondents included 65 students of Philology department and 60 of pedagogical departments. Less than a third $(29 \%)$ of the respondents mentioned that distance education is better and provides more opportunities for gaining high-quality deep knowledge. On the contrary, more than $50 \%$ believe that education in a traditional format is more interesting and rewarding due to personal communication between students and teachers. When asked what advantages of distance learning introduction are, $68 \%$ of respondents emphasized the benefits outside the educational sphere, such as time and money saving, and only a third mentioned the technological effectiveness of the learning process (the use of information technologies). Students were also asked about the difficulties they came across in the implementation of the distance education system. Half of the students (53\%) underlined the teachers' lack of the necessary knowledge and skills in creating, conducting and supporting a truly high-quality online course, the lack of necessary educational and methodological base in the University including electronic textbooks, video tutorials, presentations that would ensure effective work via the Internet, difficulties in assessment procedures.

Thus, analyzing the both surveys, we see no drastic statistical differences on the general attitude towards distance learning: about the third of the students expressed the positive attitude to it both in April and in June 2020. On the contrary, after two months of distant learning the estimated problems in terms of teaching staff readiness for distance teaching are marked by a considerably larger number of students (53\% in June 2020 as compared to $24,7 \%$ two months prior). The pragmatic usefulness of distance learning is underlined by the majority of students in both periods of the survey. This study cannot be considered large enough for the in-depth analysis and exhaustive conclusions; however, for the current work, it is sufficient to point out that university teaching staff need thorough professional development in terms of IT literacy and retraining courses. For this reason, universities should convey a large-scale 
research and allocate funds for the development of training programs and facilities.

Size limits of the article do not let us elaborate on all the drawbacks of the full-scale online education, so, taking into consideration the above-mentioned factors, we focus on the main shortcomings which are suggested below.

The first. High-quality education implies that students not only get knowledge, but also develop close relationships for the rest of their lives. If an educational establishment performs this function, the acquired social ties will then work for a student's personal life and career. In Belousova et al. (2017, p. 1916-1917) the authors state that "innovative teaching is based on the principles of dialogue, students' joint creative work, the organization of a joint learning process. These principles are the basis for the modelling of the social nature of knowledge, based on the interaction of students in the process of new knowledge acquisition. Thus, innovative methods represent the interaction of people, which is transformed into the collaborative thinking activity in the course of interaction and communication. Such collaborative thinking performance involves the development and actualization of productive cognitive, intellectual activity". Conversely, online education undermines this vital part of learning experience, as it deprives students of real-life communication. The ignorance about the consequences of this fact will result in the inability of many excellent students to impart the gained knowledge to others.

The second. If an online course is intended for a real high-quality distance learning, it must be technically supported in a proper professional way. All the lectures must be recorded by a team of experts in a professional studio. According to specialists, the production cost of one such course, containing diagrams, models, pictures, animations, examples and formulae, may reach up to 1 million rubles. If not passed on to teachers, who will have to produce home-made courses for free, such expensive online products will be obviously stored and copied for later use. This goes against the key principle of online education, which lies in the innovative up-to-date learning.

The third. Another crucial problem of online education is assessment, especially when it comes to Humanities. The test system becomes the main method of academic performance assessment. However, while tests involve pointed questions, such as "What?", "Where?" and "Who?", the nature of humanitarian knowledge deals with the questions like "Why?", "What is the aim?" and "What is the sense?" Such debating questions suggest comprehensive answers, which are only possible to get during a traditional "face-to-face" exam. Besides that, there is a widely adopted system of proctoring, which still confuses teachers, students and civil society. Proctoring during an online exam implies biometric, psychological and behavioural identification of every student as well as constant surveillance in order to eliminate cheating. Such control measures, first of all, invade students' privacy and abuse them psychologically, as everyone is suspected of cheating by default, also students' memory is assessed instead of their abilities to think and understand and, finally, it is expensive, as external proctoring systems cost around 100 rubles per hour for every person (Vasilyeva, 2020).

The fourth. The transitional period is never easy. The 2020 sudden "pandemic" transfer to distance learning is painful for both teachers and students. A lot of teachers, especially in Russian state schools, have never used IT technologies in class, although as Novković Cvetković et al. (2018) prove, the majority of teachers express the positive attitude and understanding of the necessity to incorporate IT technologies at all levels of education. Here it is appropriate to say that young teachers just out of universities prefer the employment in private schools or other spheres rather than start working in state schools. It means that state schools have more senior people in their teaching staff, most of whom are reluctant to acquire new technologies or find them extremely complicated. They experienced stress in spring 2020 and they will definitely continue being stressed further on.

\section{Commercialization and Optimization of Education}

Russia is one of the few European countries, where citizens have to pay for their education. The reduction of state-funded places goes hand in hand with the rise of tuition fees for high-demand branches, which now reach up to 540000 rubles per year. Due to this, more school leavers and their parents in Russia consider getting higher education abroad. The most popular options are Universities in Eastern Europe, such as Czech Republic and Poland, the Baltics and Finland. These countries provide relatively good education and welcome school leavers from Russia as a way to make money. The studying in such European Universities is mainly in English (B2 is the required level), however, Russian is also available for certain educational programs. Tuition costs there are significantly lower than in Russia: an academic year for Economic and Technical branches costs 3000 euros, for Humanities - 900 euros. Besides, the rankings of these Universities are similar to those of Russia's leading establishments. For example, in the 2016 Quacquarelli Symonds World University Rankings, Moscow State University took the $109^{\text {th }}$ place, while the University of Helsinki was $91^{\text {st }}$. Four Russian Universities took position in the fourth 
hundred of the ranking, such as Moscow State Technical University $\left(306^{\text {th }}\right)$, Moscow Institute of Physics and Technology and Moscow State University of Foreign Affairs $\left(350^{\text {th }}\right)$ as well as Tomsk State University $\left(377^{\text {th }}\right)$. Near them, there were several Universities from Eastern Europe, such as Charles University in Prague, Tampere University of Applied Sciences, University of Jyväskylä and Lappeenranta University of Technology (Finland), as well as the University of Tartu (Estonia) and the University of Eastern Finland (Университеты Восточной Европы дешевле российских (2017)).

University education in Russia is aimed at commercializing educational services. This makes the most promising students and next top-quality specialists choose foreign education and leads to the brain drain. The brain drain, which means losing the scientific and technical elite of the country, becomes a grave social problem and causes significant economic, cultural and political damage to the donor country.

\section{The Utopia of Digital Equality}

The debates on the equality and justice of education, both secondary and higher, were revived, as students and teachers had to go online due to the pandemic. In this light, it seems obvious that the educational system, which previously showed the unequal distribution of academic resources, now makes social inequality even worse as it keeps establishing the division into the elite with an easy access to any educational services and the mass, getting low-quality substitutes instead of the real education. The social and economic selection of University students becomes even more intense, as online education requires additional expenditures on quality gadgets, access to the Internet etc. Thus, the so-called "digital divide (Gumbrecht, 2005) is growing, and the "revolution" of online education, which has affected most Universities, signifies the establishment of digital inequality.

\section{How the University Becomes a Bureaucratic Customer-Oriented Corporation, or What Is Left of the Magna Charta Universitatum}

As known, in the 1990s, the government released higher education establishments from both ideological overseeing and appropriate funding. Universities were offered to start making money on their own. Looking for financial stability of any kind, University authorities began to introduce numerous commercial courses, most of which could not provide enough academic capacity. This caused the degradation of education quality. As the government awakened, it decided to revise the educational system by declaring state supervision of Universities and starting debates on the evil of autonomy, democracy and academic freedoms of Universities. The tendency of the top-down governance began to prevail in many Russian Universities. The administration and authorities of educational establishments appeared to be much more comfortable with the closed model of governance. These days the offices of university rectors are occupied by professional managers, not scientists, and such managers' interests are far from scientific ones, while professors and scientific staff are just contract employees.

Meanwhile, the underfunding of education and scientific research has been a permanent issue, addressed by means of optimization. It includes reorganizing and merging of Universities and their divisions, followed by name, status and policy changing, rewriting thousands of work record book pages, signing hundreds of supplemental agreements, renaming Faculties into Institutes, Institutes into Academies and Academies into Departments, inventing new titles, choosing new principals, etc. All this work requires a lot of operating staff, who multiply fast and demand considerable investment. In fact, Universities are transformed into huge conglomerates, which are very hard to control and handle. As a result, the already limited financial resources are wasted by such optimization.

As Universities constantly stay in pursuit of high rankings and are pressed by the necessity to "pay off" the money they receive as grants and state support, the teachers' workload is increasing dramatically. Overloading teachers allows to draw them down both naturally (people quit as they cannot take any more humiliations and useless work) and by carrying out specific "personnel purges". The short-term (up to one year) contract system has also taken deeper roots recently, as it ensures even more "efficient" work on education "optimization". The university lecturers are made to participate in rating procedures and to get as many rating points as possible to be reelected. The imperfection and, as a result, the absurdity of university lecturers' ratings has resulted in its transformation into a bureaucratic evaluation system.

At a time when educational environment is shrinking, teachers' primary role comes down to "tailoring" study materials to the need of the hour. Educrats believe, that such labour-consuming work allows to update the study process in line with the innovative science. In reality, however, major discoveries are made as seldom as before, and, in most cases, it is all about details - not essential for education, but time-consuming for teachers and mind-cluttering for students.

The efficiency of a University is assessed in terms of its graduates' employment. If a graduate's degree is out of demand on the labor market, their education costs have been wasted, hence, the 
University's work is considered inefficient. It is obvious that such approach is more or less suitable for training a handworker in a definite technology, but it cannot be applied to a University graduate. For example, after graduating from University with a diploma in Teaching, a young specialist is not going to work at a state school for well-known reasons, such as poor salary (although fake official reports keep stating that teachers' salaries have reached the average level), loads of paperwork and hyper-responsibility. However, the University ends up being the one to blame for graduates' employment outside their degrees, which leads to reduction of state-funded places and declaration of the University's inefficiency.

During the last quarter of the XX century, the educational systems of different countries underwent significant changes, which were brought about by neoliberal ideas and thinking, focused on resource limitations. Due to this, the economic value of higher education, the necessity to marketize educational relationships as well as the growing doubts about Liberal Arts education were put forward.

Many countries of Eastern Europe, as well as Russia, after entering the Bologna process, set a course for creating a universal educational system, which could hardly correlate with the individual educational needs. In most cases, such approach suggested the dismantlement of a national educational system. However, little did it promote the cherished goal of entering the integrated educational environment, the clear purposes of which were accessible education, equal opportunities and enhanced student mobility (which in reality appeared to be the brain drain). Such conditions do not allow maintaining high educational standards. Instead, they have to get lower to be suitable for students with average abilities and reduced motivation.

\section{The Evaluation of Liberal Arts Education Prospects in Russia}

1. The existing understanding of University as a vocational school is considered strategically wrong, as it contradicts the very spirit and sense of classical University. As a unique social institution, the University should proclaim an entirely different goal, such as formation and preservation of culture. This can be achieved by means of educating the elite, because specialties, mastered during University education, contribute to the forming of a specific cultural environment. The training of single-discipline specialists should be offered by mass education establishments, originally designed to perform this function.

2. The "forsaking" of education by the government in terms of funding is considered strategically dangerous. This situation is inevitable as long as there are commercialization and transferring of education to a fee-paying basis, and supply is determined by immediate demand and consumer preferences of a massman instead of the long-term national goals. Such model was praised by Russia's former Minister of Education A. Fursenko, who believed that the goal of education was "to nurture a qualified consumer, capable of using others' creative products professionally". The country's intellectual potential is both a major development resource and a key factor of the national security.

3. Putting University education online is considered strategically unwise. The University cannot exist without its special environment, where knowledge and ideas are formed and shared. It is the University with its unique intellectual environment, which makes the foundation of European value system. Remote education can never be compared to a Professor's work with a small group of students during a seminar class. Real face-to-face meetings of those who teach with those who study are already a privilege, which may soon be eliminated by online learning (Gumbrecht, 2005, p. 135-136). Online courses can and should be considered as a new form of study materials, supplementary to the traditional offline education, as well as an opportunity of systematic education for adult working professionals, who cannot suspend their career to study full-time (Kuzminov and Frumin, 2015). Another great application of online education would be to solve the accessibility problem and create inclusive environment for people with special needs.

4. The focus on utilitarianism and pragmatism in University education is considered strategically wrong. It is obvious that such approach is more or less suitable for training a handworker in a definite technology. However, it cannot be applied to a classical University graduate, whose mission is to develop and preserve the civic culture and carry out research as "the vanguard of science and the leader of higher education, supporting the multiplication of the intellectual elite" (Emelyanova, 2016).

\section{Conclusions}

The history of the classical University education, offering a considerable framework of Humanities, has shown its civilizational significance. According to W. von Humboldt, predomination of utilitarian and pragmatic interests and goals leads to emasculation of the very concept of the "Ideal University", which had 
a major influence on the formation of European National Universities. The process of "dehumanitarization" of education manifests itself in several most destructive tendencies, which will have a long-term impact on the quality of the civic culture. Among them, there are fragmentariness of learning and disintegration of the complex knowledge; redistribution of funding towards Science and Technology; commercialization of education and turning the University into a closed consumer-oriented bureaucratic organization without a slightest mention of academic freedoms; egalitarization of the low-quality higher education, aimed at a massman, and placing the educational system online.

Taking into consideration everything mentioned above it is necessary to make some recommendations. Firstly, Universities should be considered to be the space of culture formation and preservation through the education of the elite. Secondly, training narrow profile specialists should be the sphere of responsibility of specialized colleges and mass educational institutions specially tailored for this function. Thirdly, online courses should be regarded as a new format of teaching aids, additional instruments to the traditional offline classes, as well as a technological tool for people with disabilities and as an advanced training or retraining opportunity for those who already have a degree.

\section{Acknowledgments}

The publication is supported by Southern Federal University, Rostov-on-Don, Russia.

\section{Conflict of interests}

The authors declare no conflict of interest.

\section{References}

Abakumova, I., Bakaeva, I., Grishina, A., Dyakova, E. (2019). Active learning technologies in distance education of gifted students. International Journal of Cognitive Research in Science, Engineering and Education (IJCRSEE). 7(1), 85-94. https://doi.org/10.5937/ijcrsee1901085A

Abrosimova, L., Bogdanova, M. (2011). Культурная биограффия человека: слово и тело: Онтологическое описание [Cultural Biography of the Integral Human: Word and Body]. Saarbrücken: LAP LAMBERT: Academic Publishing.

Belousova, A., Abrosimova, L., \& Bogdanova, M. (2017). Collaborative thinking activity within innovative education structure. In Proceedings of the $11^{\text {th }}$ Annual International Technology, Education and Development Conference (Pp. 1916-1917), Valencia, Spain. https://doi.org/10.21125/INTED.2017.0577

Emelyanova, I. N. (2016) Стратегические приоритеты классического университета: контент- анализ миссий. [Strategic priorities of a classical university: mission content analysis]. Университетское управление: практика и анализ. 5(105). 4-14. Retrieved from https://www.elibrary.ru/item.asp?id=27390746

Gottlieb, A. S. (2016). Онлайн-образование в оптике преподавателей российской высшей школы. [Online education from the point of view of Russian university teachers]. Карельский научный журнал. 5. 4(17). 230-233. Retrieved from https://www.elibrary.ru/item.asp?id=27701389

Gumbrecht, H. U. (2005). Slow and brilliant: Reactions to Geoffrey Galt Harpham's diagnosis of the humanities today. New Literary History, 36(1), 131-139. Retrieved from https://www.jstor.org/stable/20057881

Jaspers, K. (1959). The Idea of the University (K. W. Deutsch, Ed.; H. A. T. Reiche and H. F. Vanderschmidt, Trans.) Boston: Beacon Press. (Original work published 1923). Retrieved from https://archive.org/stream/karl-jaspers-the-idea-of-theuniversity-1960/karl-jaspers-the-idea-of-the-university-1960djvu.txt

Keen, P. (2014). "Imagining What We Know": The Humanities in a Utilitarian Age. Humanities, 3(1), 73-87. https://doi. org/10.3390/h3010073

Khagurov, T. А. (2010). Образование в стиле «пепси» (полемические заметки). [Education in the "NEXT" style (polemical notes). Sociological studies. 7(315). 96-103. Retrieved from https://www.elibrary.ru/item.asp?id=15104231

Kuzminov, Ya.I., Frumin, I.D. (2015). Онлайн-обучение: как оно меняет структуру образования и экономику университета. Открытая дискуссия Я. И. Кузьминов - М. Карной [Online Learning: How It Affects the University Structure and Economics. Open discussion Ya.I. Kuzminov - M. Carnoy]. Educational Studies. Moscow. 3. 8-43. https:// doi:10.17323/1814-9545-2015-3-8-43

Lyotard, J. (1984). The Postmodern Condition: a Report on Knowledge (Fr. G. Bennington \& B. Massumi, Trans.). Manchester University Press. Retrieved from https://monoskop.org/images/e/e0/Lyotard_Jean-FrancoisThe_Postmodern_ Condition_A_Report_on_Knowledge.pdf

Makarova, A. E., \& Makarova, L. E. (2018). Blending Pedagogy and Digital Technology to Transform Educational Environment. International Journal of Cognitive Research in Science, Engineering and Education (IJCRSEE). 6(2). 57-66. https:// doi.org/10.5937/ijcrsee1802057M

Novković Cvetković, B., Stošić, L., \& Belousova, A. (2018). Media and Information Literacy-the Basis for Applying Digital Technologies in Teaching from the Discourse of Educational Needs of Teachers. Croatian Journal of Education: Hrvatski časopis za odgoj i obrazovanje, 20(4), 1089-1114. https://doi.org/10.15516/cje.v20i4.3001

Nureyev, В. Будущее образования в онлайне: как поменяются лекции, студенты и педагоги [The future of online education: how lectures, students and teachers will change]. Retrieved from https://trends.rbc.ru/trends/education/5f0 f2d4d9a79475e6bcc47fc 
Abrossimova, L., Bogdanova, M. \& Snezhko, G. (2020). Classical university crisis: new challenges and prospects of Russian higher education, International Journal of Cognitive Research in Science, Engineering and Education (IJCRSEE), 8(3), 135144.

Pedro, L. F. M. G., de Oliveira Barbosa, C. M. M., \& das Neves Santos, C. M. (2018). A critical review of mobile learning integration in formal educational contexts. International Journal of Educational Technology in Higher Education, 15(1), 10. https://doi.org/10.1186/s41239-018-0091-4

Pelikán, J. (1992). The Idea of the University: A Reexamination. Yale University Press; Reprint edition (February 23, 1992).

Readings, B. (1997). The University in Ruins. Harvard University Press; Edition Unstated (October 30, 1997).

Sana, F., Weston, T., \& Cepeda, N. J. (2013). Laptop multitasking hinders classroom learning for both users and nearby peers. Computers \& Education, 62, 24-31. https://doi:10.1016/j.compedu.2012.10.003

Shirky, C. (2014). Why I just asked my students to put their laptops away. Medium.com, 11. Retrieved from https://medium. com/@cshirky/why-i-just-asked-my-students-to-put-their-laptops-away-7f5f7c50f368

Vasilyeva A. (2020). На экране должны быть видны руки студента [The student's hands must be visible on the screen]. Kommersant. Retrieved from https://www.kommersant.ru/doc/4314144

Доступное образование - равные возможности? (2016). [Affordable Education - Equal Opportunities?]. Newtonew. Retrieved August 23, 2020, from https://newtonew.com/tech/digital-divide-education

Университеты Восточной Европы дешевле российских (2017). [Eastern European universities are cheaper than Russian ones]. Retrieved September 12, 2020, from http://high-study.ru/vysshee-obrazovanie-za-rubezhom/universitetyvostochnoj-evropy-deshevle-rossijskih/ 